\title{
Merâgaî’nin 'Seyahatnâme-yi İbrahim Beg’i Üzerine Bir Değerlendirme
}

\author{
Soner İ̧SiMTEKIN*
}

$\ddot{\mathbf{O z}}$

Farsça eleştiri romanlarından söz ederken, yazıldığı dönem içerisinde oldukça ses getiren ve geniş okuyucu kitlesi kazanan Hâcı Zeynülâbidîn-i Merâgaî'nin Seyahatnâme-yi İbrahim Beg ya Belâ-yi Taassub-i U (İbrahim Bey'in Seyahatnâme 'si ya da Onun Taassubunun Belast) adlı eserinden mutlaka bahsedilmelidir. 1895 - 1900 yılları arasında üç cilt halinde yazılmış olan Seyahatnâme-yi İbrahim Beg çağdaş İran edebiyatında sahip olduğu edebî öncülüğünün yanı sıra toplumsal ve tarihî büyük bir önemi de haizdir. Eserin yazarı, İran dışındaki sade nesrin en önemli temsilcilerinden biridir. Savunduğu görüşleriyle paralel biçimde ve daha çok eleştirel içerikli adı geçen bu eserini ülkesine duyduğu derin sevgi sonucunda kaleme almıştır. Yazıldığı dönemin siyasal, toplumsal ve kültürel özelliklerini yansıtan, insanların yaşadıkları zor koşulları eleştirel bakış açısıyla anlatan bu eser, sosyal bilimler alanında çalışan araştırmacılar için eşsiz bir kaynak niteliğindedir. Bu çalışmada yazarın hayatı, biçemi ve eseri değerlendirilecek, eser hakkında yapılmış olan eleştiriler karşılaştırmalı olarak verilecek, söz konusu bu eserin çağdaş İran edebiyatındaki öneminden bahsedilecektir.

Anahtar Kelimeler: Fars Dili, İran Edebiyatı, Seyahatname, Eleştirel Romanlar, Zeynülâbidîn-i Merâgaî.

\footnotetext{
* Yrd. Doç. Dr., Van Yüzüncü Y11 Üniversitesi Edebiyat Fakültesi Doğu Dilleri ve Edebiyatları Bölümü Fars Dili ve Edebiyatı ABD/Türkiye.

sonerisimtekin@yyu.edu.tr; sonerisimtekin@hotmail.com
} 


\title{
A Review on Marāga'ī's work 'Sīyāhatnāma-i Ebrāhīm Baik'
}

\begin{abstract}
Referring to Persian literary criticism, the work Sīyāhatnāma-i Ebrāhīm Baik ya Balâ-yi Taassob-e O (The Travel Diary of Ebrahim Beg or the Trouble of His Bigotry) by Hajj Zayn al-Ābedīn Marāga'̄̄, a prominent and widely-read author among his contemporaries, should certainly be addressed. Besides being a pioneer in the Persian literature, Sīyāhatnāma, which was written in three volumes between 1895 and 1900, has a great social and historical significance as well. The author of the book is one of the most important representatives of simple prose outside of Iran and he wrote this book as a result of his deep love for his country. This groundbreaking work of him, reflecting political, social, and cultural characteristics and difficulties in historical cycle of life in that time period from a critical view, represents an indispensable historical and literature source for social scientists. In the present paper, the life of this prominent novelist, his writing style and works will be reviewed. The criticisms pertaining to his seminal work will be comparatively provided, and the place of this work in the contemporary Persian literature will be highlighted.
\end{abstract}

Keywords: Persian Language, Persian Literature, Travelbook, Critical Novels/Literary Criticism, Zayn al-Ā'bedīn Marāga'̄̄. 


\section{Giriş}

On dokuzuncu yüzyılda İran'da anayasal düzenin oluşmasını arzulayan ve halkı bu doğrultuda bilinçlendirmek isteyen birçok edebiyatçı, eserlerinde meşrutiyetin anlamından söz ederek onları Avrupa medeniyetinden haberdar etmeye çalışmışlardır. Ancak ülkelerinde düşüncelerini özgürce dile getiremediklerinden bu ediplerden bazıları çalışmalarını yurtdışında sürdürmeye karar vermişler; Türkiye, Mısır, Hindistan ve çeşitli Avrupa ülkelerinde gazete, kitap ve dergiler yayımlayarak, İran yönetimine karşı eleştirel düşüncelerini en üst perdeden ifade etmişlerdir. Yazınlarını ise gizlilik içerisinde İran'a göndererek halkı gerek siyasal gerekse kültürel açıdan eğitmeye çalışmışlardır. Bunu yaparken de görüşlerini halkın rahatça anlayabileceği sade bir dil ve üslupla ifade etmişlerdir. Bunlardan Mirzâ Abdurrahîm Tâlibof, Zeynülâbidîn-i Merâgaî, Mirzâ Malkom Han, Seyyid Cemaleddin-i Afganî, Mirzâ Aka Han-i Kirmanî, Şeyh Ahmed-i Ruhî ve Mirzâ Habib-î İsfahanî öne çıkan isimler olarak sıralanabilir (Kanar 1999: 86). Bu bağlamda, Farsça eleştiri tarzındaki romanlardan ve yazarlardan bahsedilirken, yazıldığı dönem içerisinde oldukça ses getiren ve geniş bir okuyucu kitlesi kazanan Hâcı Zeynülâbidin-i Merâgaî'ye ait Seyahatnâme-yi İbrahim Beg Ya Belâ-yi Taassub'u U adlı eser öncelikli olarak incelenmelidir.

\section{Yazarın Hayatı}

Hâcı Zeynülâbidîn-i Merâgaî, 1slahat taraftarı ve özgürlükçüler safinda yer alan ve Azerbaycanlı zengin bir tüccar olan Meşhedî Ali’nin oğludur. Yazarın soyu aslen Mâhâbâd Kürtlerine dayanmaktadır. Merâga’ya göç edip orada ticaretle uğraşan aile, daha önceleri Sünni fikhının Şâfî̂ mezhebine bağlıyken sonraları Şia mezhebine geçmiştir (Sobhânî 1384: 586; Âryenpûr 1379: 304). Zeynülâbidîn, hk.1255/ m.1839 senesinde Batı Azerbaycan'daki Merâga şehrinde doğmuştur. Yazar yedi yaşında ilkokula başlamış ve sekiz sene okula devam etmiştir. Henüz 
on altı yaşındayken babasının yanında çalışmaya başlamıştır (Kanar 1999: 93; Âryenpûr 1379: 304). Babasının Merâga'daki işlerinin ters gitmesi ve servetini kaybetmesi üzerine yirmi yaşında Erdebil'e giderek ticaret hayatına atılmış; ancak pek başarılı olamamıştır (Merâgaî 1323: 11). Bunun üzerine Kafkasya'ya, Gürcistan'ın Başkenti Tiflis'e gitmiştir. Ticaretin yanında siyasetle de ilgilenmiş, burada İran başkonsolosu Esedullah Han Nizamu'd-Devle'nin yardımcısı olmuştur. Merâgaî, bu görevdeyken yabancı ülkelerde ikamet eden İranlılara yardım amacıyla birçok girişimde bulunduğunu belirtmiş̧ir. İnsanlara gelişigüzel yardım eden ve parasının hesabını bilmeyerek sermayesini kaybeden yazar, Tiflis'i terk ederek Kırım'da kardeşiyle başka bir iş kurmuştur. İstanbul'a gidip oradan getirdiği malları burada satmaya başlamıştır (Merâgaî 1323: 11; Âryenpûr 1379: 305). 1877 yılında Osmanlı-Rus savaşı çıktığında iki kardeş imparatorun yazlık sarayının bulunduğu Yalta'ya gitmiş ve burada da ticaretle uğraşmışlardır. Uzun süre Yalta'da kalan yazar, Rus sarayının ilgisini kazanmış hatta 'dürüst İranlı tüccar' lakabıyla anılmaya başlamıştır. İstanbul'daki İran konsolosluğunda maruz kaldığ onur kırıcı hareketler neticesinde, Yalta'daki saray ileri gelenlerinin de tavsiyesi üzerine, Rus vatandaşlığına geçmiştir. Birkaç sene sonra İstanbul'da evlenip eşini de çok geçmeden Yalta'ya getirtmiştir. Burada üç çocuğu olan Merâgaî, İran vatandaşlığından çıktığı için sürekli suçluluk duygusu hissetmiş, kendisini her daim ihanetle itham etmiştir. Sonunda vatan sevgisi ağır basan yazar, her ne kadar düşünceleri dolayısıyla İran'a gidemese de, tüm malını mülkünü değerinden daha ucuza satarak ailesiyle İstanbul'a yerleşmiş ve İran elçiliğine başvurarak tekrar İran vatandaşlığına geçmiştir. Bu dönemde ailesini bir süre İstanbul'da bırakarak Mekke'ye Hacca da gitmiştir. İstanbul'da ömrünün sonuna kadar kalmaya karar veren ve siyasal mücadelelerini kalemiyle sürdüren Merâgaî, İstanbul' da yayımlanan Şems ve Ahter gazetelerinde çalışmış, aynı zamanda Hindistan'da çıkartılan Hablu'l-metin gazetesine de daha çok eleştirel içerikli makale ve yazılarını göndermiştir. Zeynülâbidîn 1910 yılında, yetmiş üç yaşında İstanbul'da vefat etmiştir (Kanar 1999: 93; Sobhânî 1384: 587).

\section{Seyahatnâme-yi İbrahim Beg ya Belâ-yi Taassub-i U'ya Dair}

Eserin içeriğine değinmeden önce kitabın basım tarihleri ve basım yerlerinden söz etmek yararlı olacaktır. Yazarının kendini tam on iki sene sonra tanıtt1- 
ğı, eleştiri yüklü, siyasi bir eser olan ve biyografik bir roman olarak değerlendirilebilecek Seyahatnâme-i İbrahim beg ya belâ-yi taassub-i U'nun ilk cildi, Nasıruddin Şah'ın hayatının ve saltanatının son zamanlarında, 1895 senesinde yayımlanmıştır. Kitabın ikinci cildi birinci cildinin basımından bir sene sonra yani Muzafferuddîn Şah zamanında, 1896'da yayımlanmıştır. Üçüncü cilt ise 1900 senesinde basılmıştır. Yazar aslında son cildi 1897 'te tamamlamış; fakat Muhammet Ali Şahın korkusundan yayımlanmasını ertelemiştir. Kitapların basım yerleri ise Kahire, Kalküta ve Lahor gibi şehirlerdir.

Eser, İbrahim Bey isimli başkarakterle öykülenmektedir. İbrahim Bey, ticaret amacıyla gittiği Mısır'da kısa sürede büyük servet kazanan Azerbaycan asıllı İranlı büyük bir tüccarın oğludur. Bu tüccar ahlâkl1, millî gelenek ve göreneklerinden vazgeçmemiş birisidir. İran sevgisi o denli ileridir ki Mısır'a gelmesinin ardından birkaç sene kimseyle tek kelime Arapça dahi konuşmamış hatta Arapçayı öğrenmek bile istememiştir. İbrahim Bey bu tüccarın akıllı, çalışkan, muhafazakâr ve namuslu oğludur. Ana dilinin yanı sıra yabancı dil öğrenmiş ve mektepte çeşitli bilimler okumuştur. Babası gibi sürekli yurt özlemi çeken İbrahim Bey yirmi yaşına bastığında babasını kaybetmiştir. Babası ölüm döşeğindeyken oğluna, hayata dair tavsiyeler vermiştir. Annesine iyi davranması, namazı terk etmemesi gibi isteklerin olduğu altı madde sıralamış, bu bağlamda otuz yaşına gelene kadar dünyanın her yerini görmesini, canı her nereye gitmek istiyorsa oraya gitmesini; gittiği her yerde birkaç gün kalmasını, halkın yaşantısını iyice gözlemlemesini ve gördüklerini günlük olarak kendi eliyle, o şehre veya beldeye giriş ve çıkış tarihini de ekleyerek kaleme almasını da vasiyet etmiştir (Merâgaî 1323: 27-28).

İbrahim Bey, Mahbube isimli bir akrabasını sevmektedir lakin onun en büyük aşk1 "İran Hanım” olarak nitelendirdiği vatanıdır. İran'ın tarih kitaplarında bahsedilen eski görkemi ve yazarın bu durumun devam ettiğini düşünmesi ondaki vatan sevgisini kat be kat arttırmaktadır. Hatta İran'la ilgili en küçük bir olumsuz habere dahi inanmamakta ve bunu kabul etmemektedir. Bu duygularla en sonunda sevdiği ülkesini görmek ve Sekizinci İmam’ı ziyaret etmek için Osmanlı yoluyla İran'a gitmeye karar verir. Bu andan itibaren hikâye gitgide temsili bir anlatıya dönüşmektedir. Yurdundan yıllar yılı uzak kalmış olan İbra- 
him Bey nihayetinde yolculuğa çıkar. Demir yolu ile Mısır'dan İskenderiye’ye doğru yola koyulur ve oradan İstanbul'a ulaşır. İstanbul' da hikâyenin yazarıyla; yani Merâgaî ile görüşür ve onun evinde Talîbof'un eseri Kitab-i Ahmed'in bir kopyasını görür ve okur. Tabiî olarak İbrahim Bey bu kitapta İran'a karşı yazılan olumsuz haberlere inanmaz ve hatta kitabın yazarına serzenişte bulunur. Talîbof'un İran hakkındaki bilgisizliğini, kitabın basımındaki eksiklikleri ve yanlışları eleştirir, yazarı İran'a yabancı kalmakla itham eder. Ev sahibine yazdığı mektubunda şöyle söyler: "Her ne kadar kitabın yazarı âlim ve bilgili bir adam gibi görünse de, oldukça önemli konulardan bahsetmiş olsa da kesinlikle Iran'dan habersiz biridir, belki de bizden biri (İranlı) bile değildir." (Merâgaî 1323: 37). İbrahim Bey, İstanbul'dan Batum'a doğru tekrar yola çıkar ve Tiflis, Bakü, Enzelî, Sarî, Meşhedser, Uzunâdâ ve Aşkâbâd şehirlerinden geçerek Meşhed'e ulaşmayı hedefler. Kafkasya'ya ulaştığında orada yaşayan İranlıların katlanmak zorunda kaldıkları kötü duruma ve çektikleri sıkıntılara ilk kez yakından şahit olur. Özellikle Batum'a vardığında ve orada İranlıları, onların perişan halini, onların yırtık pırtık, eski elbiselerini, yüzlerindeki zayıflığı ve sarılığı görünce, hele ki oradaki bir hemşerisinden tüm Kafkas şehirlerinde ve kasabalarda hatta Osmanl, Rusya ve Hindistan'da dahi İranlıların bu durumda olduğunu, sabahtan akşama kadar yakıcı güneşin altında amelelik yaptıklarını duyduğunda büyük bir keder yaşar. Sonra kendisini teselli etmek için buraların gurbet olduğunu söyleyerek aslında İran'da güvenli ve emniyetli, huzurlu bir ortamın olduğuna inanır. İbrahim Bey, İran'a varana dek hikâye bu biçimde örüntülenmektedir.

\footnotetext{
“...Faytoncu şöyle dedi: "Işsaretin o tarafi Iran toprağ bu taraf ise Rus topră̆ldır.”

Faytoncuya biraz durmamı gerektiğini, biraz işimin olduğunu söyledim. O ise benim başka bir hacetimin olduğunu düşünerek, "Biraz bekle su yakındır, orada inersiniz" dedi.

Bense: "Suya ihtiyacım yok, benim işim toprakla" dedim.

$O$ da faytonu durdurdu. Aşağlya inip temiz topraktan bir avuç aldım, öpüp kokladım ve yüzüme sürdüm: "Ey temiz türbe, ey nemli gözlerin mücevher sürmesi! Tanrlya şükürler olsun ki bir gün seni bana gösterdi. Gözüm seni görmekten parladı. Sen ki ihtiyacı olanların sığınă̆l ve ataların mezarısın. Sen ki, kendi nazlı beşiğinde bizi büyüttün, nazı ve izzeti bize gösterdin. Seni sevmekten başka senin hakkını ödeyemeyiz. O ne büyük ve ulu bir haktır. Duaların ve selamların ulusu ve yücesi, Íslam'ın mukaddes şartlarında ve hak bilirlerin
} 
terazisinde senin sevgini iman ile aynı kefeye koymuştur. Senin güneşe eşdeğer yüksek kadrini, değerini nitelemek için artık ben ne diyeyim?"

Velhasıl kelam boğazımda bir ağıt düğümlendi ve gözyaşım gayr-ı ihtiyari o temiz toprağa aktı. Bir süre dertli gönlümün arzusuyla mutluluktan ağladım. Iyi biliyordum, o gözyaşının lezzeti ebediyen gönlümün bir köşsesinde kalacaktı.

Faytoncu büyük bir hayretle bana bakıyordu. Sonunda şaşkınlıkla şöyle söyledi: "Aferin sana hacı oğlu, ben birkaç senedir bu yoldan gidip gelmekteyim lakin vatan topră̆ına senin kadar değer veren birini ilk defa gördüm. Benim gönlüm de bu yolculukta dağlandı. Biz Gence halkındanız. Ben de senin gibi vatan toprağını severim. Bizim ülkemiz, yöneticilerin düşüncesizliklerinden bedbaht oldu. Bildiğiniz üzere şimdi müezzin sesi yerine çan sesi var. Elden ne gelir? Ĕger Iran devleti devlet olsaydl, kendi memleketine kanun, düzen ve eşitlik getirir kendi halkın yöneticilere hayvan fiyatına sattırmazdı. Biz de bizim düşmanımız olan yabancıların zorbalığına katlanmaz ve Iran'a dönerdik..." (Merâgaî 1323: 51).

Kendini bu şekilde kandırarak İran'a ulaşır; fakat her nereye gitse bir musibetle, olumsuz bir tabloyla karşılaşır. İbrahim Bey için gerçeği kabullenmek çok ağır ve acıdır. Ancak bundan daha acı olan şey, İbrahim Bey'in bunu dile getirememesi ve bu gerçeği kabul edememesidir.

“... Ansızın diğer taraftan yüksek bir ses yankılandı. Her taraftan bağırıyorlardl: "Öne çık, hadi, elbisenin önünü düzelt."

Büyük bir şaşkınlıkla oraya doğru baktım. Bıyıkları kaytan, uzun boylu bir genç gördüm, ata binmiş geliyordu. Ellerinde uzun sopalar olan otuz kırk kişi ise onun iki tarafinda düzenli bir sira halinde ilerliyordu. Onların en önünde esmer, şeytan yüzlü biri ve arkalarında da on yirmi kişilik bir süvari taburu vardi.

Rıza Ă̆a'ya bu kargaşa nedir diye sordum. Şehrin valisi olduğunu ve ava gittiğini söyledi: "Onun yanından geçerken, diğerlerinin yaptı̆̆ gibi saygı duruşunda bulunup baş ĕgip selam veriniz."

Daha iyi baktığımda dört bir yandan insanların ona secde ettiklerini gördüm. O da büyük bir edayla, bir sağdan bir soldan kaytan bıyıklarını buruyordu.

Dedim ki: "Selam vermezsek ne olur?"

"Şunların sopaları bir tarafinı inletirler, yoksa canına kastın mı var?" dedi.

Ben de "Yok yok, daha yaşamak istediğim bin bir çeşit arzum var." diye mırildandım.

Nihayetinde sağda durup valinin kortejinin geçişi esnasında biz de tam bir tevazu ve sayglyla eğildik. Bela yaklaşmış ancak çok şükür hayırlısıyla geçip gitmişsi. Şimdiye kadar böyle bir şeyi hiçbir yerde görmemiştim.

Çok şaşırmıştım ve şöyle söyledim: "İran sen çok yaşa, yedi milyon nüfusu olan Londra'nın valisi her yerden bir başına geçiyor da hiç kimse onun şanına özen bile göstermiyor; maşallah bizim küçük bir eyaletimizin valisinin büyüklüğ̈̈ne, şu topluluğa da bak. Isşte saltanat dediğin böyle olmalı!”

"Rıza Ăga, hâkim bütün bu topluluğun yiyeceğini ve maaşını nerden sağll- 
yor?" diye sordum.

"Bunların maaşl yok ki." dedi.

Sordum: "Öyleyse ne yiyorlar, nasll geçiniyorlar?"

"Sabahtan akşama kadar sokakta, pazarda dolanırlar. Her nerde iki kişi birbirleriyle münakaşa, kavga etse derhal onlarl görevli memurun yanına götürürler. Kavga her zaman önemsizdir. İki tümeni memur, beş kranı naib ve iki üç kran da bu görevliler alip onlart serbest birakirlar. Her ne zaman etraftaki köylerden bir ricacı gelse, bu görevli süvariler bir kaç tümen için dörtnala koşar gelirler. Eğer kavga büyükse, ileri gelenler veya emirler ya da tüfekçi başı, sucu, kahveci gibi kimseler de işe el atarlar, o zaman elli veya yüz tümeni şehzade için, on yirmi tümeni de kendileri için tekellüf veya para cezası adı altında alırlar." diye ekledi.

Ben bu sözleri işitince yerimde kuruyup kaldim ve seyahatimden nefret ettim. Kendi kendime: "Ah, keşke kör săgır olsaydım da bu durumu görmeseydim, bu sözleri duymasaydım. Türlü zahmet çekerek, para vererek belanın hasını kendi kendime satın mı aldım?" dedim..." (Merâgaî 1323: 64).

İbrahim Bey mevcut duruma teslim olmak istemediğinden, canı gibi sevdiği İran'ın iyileşmesi için çareler ve çözüm yollarının peşine düşer. Toplumun bilinçsizliği, ülkenin geri kalmışlığı konusunda duyarsız kalan yöneticilerden sıradan insanlara kadar birçok sosyal sınıfa ait insanın katıldığı bir miting düzenler. Üst düzey yetkili insanlara kadar herkesi toplayıp dinî ve millî vazifeleri doğrultusunda ne yapmaları gerektiğini gösterir ve onlara bu olguları tanıtır. Ancak "isimleri kulağa hoş gelen devlet makamlarına başvurarak, onları reform yapmaya teşvik etmek isterse de bir sonuç alamaz." (Âbidînî 2002: 7-8) İbrahim Bey'in çabaları boşunadır ve tümü sonuçsuz kalır. Her nereye gitse onu hayal kırklığına uğratan hadiselerle karşılaşır. Ülkenin malî ve ekonomik açıdan ilerlemesi, millî sanayinin gelişmesi, yabancı devletlerin imtiyazlarının iptal edilmesi, kültür ve eğitim gibi alanlarda sslahatların yapılması amacıyla insanlara tavsiyelerde bulunduğunda, çoğu kez fuzulî işlerle insanları oyalıyor diye onunla alay edip ona ağır hakaretlerde bulunurlar hatta onu döverler.

“...Ertesi gün, öğlene doğru - kervansarayın çevresinde bulunan ve bizim konakladığımı yere de yakın olan Mescid-i Cum 'â'ya, namazı orada kılalım diye gittik. Bu mescit baştanbaşa medrese ve öğrenci yurdu, avlunun ortasında da berrak bir su çeşmesi var. Abdest alıp mescidin içine girdik. Mescidin bir tarafinı kavun ambarı olarak kullandıklarını gördüm. Bu durumu görünce birden gözüm döndü. Diğer tarafa bakınca iki kişinin oturmuş olduklarını gördüm. Yaklaşıp birine sordum: "Amca, bu kavunlar kime ait?”

"Benim” dedi. Bu kez "Bu dükkân kimindir?” diye sordum.

"Müminlerin! Burası mescittir, dükkân değil görmüyor musun? Bu kadar bü- 
yük bir dükkân nerde görülmüş?!"

Dedim ki "Mescit kimindir?"

Dedi ki "Mescit kimsenin malı olamaz, Allah'ın evidir."

"E, ne kadar kira veriyorsun?" diye sordum.

"Hiç" dedi.

"Peki, Allah buna razı mı? Sen bu temiz yeri ambar yapmıssın, kira vermeden kavunlarını satıyorsun.”

"Ben ne bileyim." dedi.

Dedim ki “Amca, Allah'ın kendi için ibadethane kılmış olduğu, herkesçe o yere saygı duyulması vacip olan, girerken çıkarken her Müslüman'ın uyması gereken özel kuralların, şartların olduğu böyle bir yeri sen kavun ambarı yapmışsın Allah'tan korkmuyor musun? Bu senin yaptığ iş mescide, mezhebe ve şeriata saygısızlıktır. Acaba hiçbir Hıristiyan'ın kiliseleri kavun ambarı yaptığını duyup gördün mü? Allah'tan ve Allah'ın peygamberinden hiç mi utanmıyorsun? Müslümanlar burayl, İslamiyet'i benimsemiş diğer Müslümanların toplanması, Allah'ın adını, birliğini zikredip namaz kllmaları için, ibadet etmeleri için yapmışlar. Islam bilginleri burada insanlara vaaz ve nasihat veriyorlar, onlara zorunlu olan hükümleri ögretiyorlar, Yüce Allah İslam' l yüceltsin, padişahı din düşmanlarına karşı başarılı ve muzaffer kılsın, Müslümanlar, Allah'ın yüce kelimeleri arasında dostluk ve ittifak yapıp nifak ve düşmanlığl aradan atsınlar diye tüm Müslümanlar için tanrıdan mağfiret dileyip dua ediyorlar. Yoksa sizin şehrinizde âlim yok mu ya da bu şehrin bilginleri Allah'tan korkmuyorlar mı? İslam'ın hürmetine ve Müslümanlığın farzına engel olan bu yakışıssız durumlara neden engel olmuyorlar? Klyamet gününde Allah'ın sorusuna nasll cevap verecekler? Allah'ım! Bu dermansız dertlere nerede deva arayayım! Hangi büyük günahın cezası olarak böylesine karanlık bir güne hapsoldum da her an yeni bir dert istikbalime parlyyor bilmiyorum! Bu nasıl bir Müslümanlıktır? Ah bugün ardından bir yarın olsa!’... (Merâgaî 1323: 166-167).

İbrahim Bey bu şekilde İran'ın şehirlerini ve beldelerini ziyaretine devam eder; her gittiği yerde aynı kötü muamele ile karşılaşır. Sonunda büyük bir hayal kırıklı̆̆ı ve derin bir üzüntü ile geri dönmek ister. Kazvîn, Erdebil, Merâga, Bunâb ve Urmiye şehirlerini gördükten sonra Tebriz'e geçer ve oradan Merend ve Aras yoluyla tekrar Batum'a gider ve nihayetinde Misır'a döner. Babasının vasiyeti üzerine başlayan kendi seyahatnâmesini tamamlar; ancak hikâye burada bitmez. Onun akıl hocası ve lalası, Yusuf Amca bu yolculukta ona eşlik etmiştir ve hikâyenin geri kalanını artık o devam ettirmektedir. Yusuf Amca'nın anlatımına göre, İbrahim Bey gurbette duçar olduğu yıpranmış sinirleri ile mitingler düzenlemekten geri durmaz. En sonunda bir gece düzenlediği mitingde çıkan bir yangın sonucunda yaralanır. "Onun taassubunun belası" başlığındaki ilk cilt bu şekilde sona erer. 
Eserin ikinci cildi, “Onun taassubunun neticesi” başlığıyla, Yusuf Amca’nın ağzından devam eder. İbrahim Bey kendine geldiğinde aklını ve duyularını nerdeyse yitirmiş, fiziksel olarak da oldukça yıpranmıştır. İran'a duyduğu derin sevgi neticesinde, İran'ın içler acısı haline tanık olmaktan dolayı sağlığını kaybeden İbrahim Bey'in kendine gelebilmesi ve hastalığından kurtulabilmesi ya da hastalığının daha da ağırlaşması durumu artık İran'dan gelecek iyi veya kötü haberlere bağlıdır.

[Mısır'a dönen ve seyahati esnasında İran'da gördüğü olumsuzluklardan ötürü hastalanıp yatağa düşen İbrahim Bey’e annesi] “...Canım, İbrahim, benim, annen; (bak ben) geldim. Konuş benimle, seninle sohbet etmek istiyorum. Neden bu duruma düşün? Neren acıyor? Senin o tatl diline kurban olayım. Niçin anneciğine acımiyorsun?"dedi. Her ne kadar râz $\hat{u}$ niyâzz gösterdiyse de bir cevap alamadl... Hekim geldi ama ne hekim, faydası! Aynı tas aynı hamam!... Akşam ezanı okundu. Sanki İbrahim Bey bazı şeyleri duyuyor ya da hissediyordu. Ne zaman ki Allahû Ekber sesini işitse [sadece] "Yâ hakk yâ meded!" diyordu..." (Merâgaî 1323: 318).

“...Hekim bir İbrahim Bey'e baktt, dönüp [sonra da] bana baktt. Bi ihtiyari şekilde omuzlarını yukarı çekip ima ve işaret ederek "Bu nasıl bir durum?" diye sordu. Öne doğru ilerleyip selam verdi, halini hatırin sordu ancak bir cevap alamadı. Nabzını ölçtü, bir şey anlamadl. Ateşini ölçmek için termometre koydu ama [ateşini de] normal buldu. Göğsünü ve sırtını eliyle vurarak dinledi. Her şeyi yerli yerinde ve sapasağlam gördü: "Subhanallah! Kırk yıldır pratik (uygulama) yapartm ne böyle hasta ne de böyle hastallk gördüm" dedi." (Merâgaî 1323: 325).

“... İbrahim Bey'in yanına gittim. Uyumuştu. [Annesi] Haciye Hanım ayağıno okşuyordu. Bir müddet oturup Haciye Hanım'a: "Eğer iznin olursa yarım saatliğine hamama gideyim" dedim. İzin verdi. Gidip döndüm. [Benimle beraber] gelmiş olan birkaç arkadaş, Haciye Hanım'in dışarı çıması ve İbrahim Bey'i görmek için ricada bulundular. İbrahim Bey'in yanına gittim. Sanki tuzağa düşmüs bir ceylan misali hasret dolu bakışı gönlü yaklyor, kavuruyordu. Şair Mehdî Bey: "Eyvahlar olsun, bu İbrahim Bey mi? Ondan geriye bir şey kalmamış. Bir insanın bu şekilde değişeceğine asla inanmıyorum" diye bağlrıp çağırdl. Sorular sordular lakin cevap alamadılar. Mehdî Bey: "Hakikaten bu genci böyle görmeye dayanamıyorum. Allahalsmarladık!" dedi, kalktı ve gitti." (Merâgaî 1323: 331).

“... Mahbube odaya girip oldukça edepli, utangaç ve çekingen bir vaziyette selam verip de bir cevap işitemediğinde öne ilerledi ve "Ey efendim, ey habibi!" diye bağırdl. Ağlayarak, inleyerek kendini İbrahim Bey'in yatağının ucuna attı ve ayaklarını kucağına çekip şöyle söyledi: "Ey efendim, ey 
kalbimin sahibi! Daha ne zamana kadar senin üzüntünde bir mum gibi eriyeyim, aşkının ateşinde yanayım. Daha ne kadar seni bekleyeyim, ne kadar ağlayayım? Ăgacı̆̆ım, senin bu küçücük hizmetçin dokuz ay gözünü İran yoluna dikti, oturup seni bekledi. Seni bu halde görsün diye mi? Kim senin gönlüne teselli verenin? Kim senin zülfü amber kokulun? Çam ağacı gibi endamın neden eğildi? Ayă̆ına nerede keder dikeni battı? Feleğin hangi bozuk yolundan geçtim de bu bela toprağ başıma saçıldı? 'Ibrahim Bey mazlum bir şekilde bakıp: [sadece] “yâ hakk yâ meded!’dedi (Merâgaî 1323: 338).

“... Ö̆gle yemeği vakti geldi. Bir kaba sütlaç koymuşlardl. Ben de oturdum. Mahbube, İbrahim Bey'i bir yasttğa dayad. Zavallı, kaşı̆̆ İbrahim Bey'in eline vermek istedi ama o tutamad. Mahbube, onun sallanan elini, elinde kașığ olan bir yaşındaki bebeğin elini tutar gibi tutuyor, kaşı̆̆ı zorla onun ağzına sokmak istiyor ama beceremiyordu." (Merâgaî 1323: 340).

***

“...[İbrahim Bey şöyle diyordu:] Yusuf Amca, gazeteler kanun hakkında ne yazıyorlar? Geçmiş mi, uygulamaya koymuşlar mı koymamışlar mı?...” "Validem, sen neden ağllyorsun? N'oldu?" Biçarenin sanki olan bitenden hiç haberi yoktu. Mahbube şimdi [iyice] utangaçlaşmış, içeriye giremiyor ve [sadece] aradan baklyordu." (Merâgaî 1323: 403).

Muzafferuddîn Şah'ın padişah olması, toplumsal ve siyasal sslahatların başlaması haberi İbrahim Bey'in sağlık durumunda kısa süreli bir iyileşmeye sebep olur. Sevgilisi Mahbube Hanım'la sözlenir. Lakin yapılan bu 1slahatların kısa sürede sekteye uğraması, 1slahatların mimarı sayılabilecek Sadrazam Eminu'dDevle'nin azledilmesi, yönetim kadrolarının tekrar eski, dar kafalı insanların eline geçmesi gibi İran'dan gelen kötü haberlerle sağlığı günden güne daha da bozulur. 'İran Hanım' diye sevdiği biricik aşkı İran'ın can çekiştiğini gören İbrahim Bey bu acıya dayanamaz ve mutsuz bir şekilde, nişanlısıyla birlikte ikinci cildin sonunda dünyaya veda eder.

Üçüncü cilt hakkında yapılan değerlendirmeler Merâgaî’nin kitabı yazmaya başladığında bu cildi yazmayı düşünmediği ancak ilk iki cildin başarısı ve gösterilen ilgiyi görünce yazmaya karar verdiği yönündedir. Bu ciltte yazarın kendinin veya başka yazar ve şairlerin yazdığı ahlakî şiirlerin, bazı makale ve kıtaların sıkça kullanılması bu görüşü desteklemektedir. Bu bölümde, Yusuf Amca, Mısır'dadır ve rüyasında yaşlı bir rehberin eşliğinde diğer dünyaya gider ve yolculuğu esnasında gördüğü olayları anlatır, bu bakımdan üçüncü cilt Dante'nin ‘Ilahi Komedya'sına benzetilmektedir. İran'da yaşanan batıl inançla- 
ra da yoğun eleştirinin yapıldığı bu ciltte Yusuf Amca, cennette İbrahim Bey’le karşılaşır ve İbrahim Bey'in İran'ın çektiği sıkıntılar hakkında aynı taassup ve duygularla dolu olduğuna, oradaki diğer insanlarla benzer konuşmalar yaptığına ve kavgalar ettiğine aynı şekilde şahit olur.

[Rüyasında diğer âleme giden Yusuf Amca’ya] “...Yaşlı adam sordu: “Adını ve şehrini söyle!"

"Adım Yusuf, babam Abdullah, doğum yerim İran, yaşadı̆̆ım yer Misır. Burada garip ve kimsesizim” dedim. Yaşlı adam yukarıya çıktı, bense sabırsız onun geri dönmesini bekledim. Kısa süre sonra biri erkek diğeri kadın iki kişinin kafası odanın kapısından dışarıya uzandı ve birbirlerine beni gösterip şöyle söylediler: "Evet, o!"

Elleri ve ellerindeki mendille bana işaret edip, "yukarl gel!' dediler. Bu esnada yaşlı adam hızlıca geri geldi ve merdivenin başından beni işaret ederek "gel" diye buyurdu. Gittim, yaşlı adam dedi ki: "Şansın yaver gitti; talihin rehberin olsun, yüksek bahtınsa muradına ersin, güçlü atın seni arzuna taşısın. Onlar seni tanıdılar, onların iştiyakları senden [kat be kat] daha fazla."

Yukarı çıktım, onları gördüm. Her ikisi de boynuma sarılıp beni kucakladılar. Onların bu davranışından ötürü hayrete düştüm. Şakayı seven neşeli büyüklerimizin kendilerini eğlendirmek için beni alaya aldıklarını zannettim. Böyle çok büyüğümüz ve ileri gelenimiz var. Bir fakir, bir garip ya da bir yaşll gördüler mi böyle alay ederler. Bu davranışın bana yapılan bir şaka olduğunu düşünerek kendimi geriye çekip şöyle söyledim: "Estafurullah! Ben sizin sandiğınız o insanlardan değilim. Acaba hangi meziyetim beni bu sonsuz lütufa şayeste kilmakta?"

"Yoksa bizi tanımadın mı?" diye sordular.

"Hayır" dedim.

Genç çocuk parmağıyla göğsünü işaret ederek, "Yusuf Amcacı̆̆ım, benim [ben] İbrahim!” dedi. Kiz da kendi öğretmeninden öğrenmiş olduğu üzere, sakin ve övülecek bir biçimde, sol ayağını az geriye, să̆ ayağını ise birazcık öne doğru atmış, kendini saygl ve hürmetle öne doğru ĕgmiş ve iki elini göğsünün üzerinde bağlamış bir halde: "Amcacım, [benim] naçiz kulunuz Mahbube!" dedi. (Merâgaî 1323: 581).

Uyandığında rüyasını tabir etmeleri için ulemaya başvurur, yaşanan acı olayların ve çekilen binlerce üzüntünün ardından yine de bir ümidin var olduğunu öğrenir. Yazar buradan itibaren uzun uzadıya İran'ın en ünlü şair ve yazarlarının öğüt ve ahlakî içerikli beyitlerine ve söylemlerine yer verir. Verdiği alıntılarla daha çok halkı bilinçli olmaya ve ülkenin gelişmesine, ilerlemesine katk1 vermeye davet eden yazar son sözünü şu şiirle bitirmiştir: 
Ey vatandaşlarım uykudan uyanınız

Kibir ve naz sarhoşluğundan uyanıp akıllanınız

Gafletten ve nifaktan uzaklaşınız

Vatanı korumada birbirinize dost olunuz.

\section{Seyahatnâme'nin Toplumsal Etkisi ve Tarihî Önemi}

Seyahatnâme-i İbrahim Bey'in gerek toplumsal gerekse edebî bakımdan oldukça etkin bir çalışma olduğunu söylemektedir Muhammed Ali Ekber (1384: 72). Eleştirmenler, eserin İran meşrutiyet inkılâbının gerçekleşmesinde sahip olduğu sosyal önemin, Fransız Devrimi'nin gerçekleşmesinde pay sahibi olan Jean Jacques Rousseau'nun toplumsal eserleri kadar büyük olduğu görüşündedirler. Bu görüşe göre, eleştirmenler eserin toplumsal etkileri ve önemiyle ilgili aşağıda yer alan yorum ve tespitlerde bulunmuşlardır:

Edward Granville Browne, Seyahatnâme'nin yazıldığı dönemde İran halk1 tarafından çok beğenildiğini ve Muzafferuddîn Şah'ın saltanatı esnasında hükümete karşı duyulan nefretin tahrik edilmesinde ve yaşanan isyanlarda önemli bir rol üstlendiğini söylemiştir. Meşrutiyet dönemi gazeteci ve yazarlarından olan Nâzımu'l-İslâm-i Kirmânî, Târîh-i Bîdârî-yi İânîyân adlı çalışmasında, Seyahatnâme için şöyle bir görüş bildirmiştir: "Meşrutiyetten önce özgürlük yanlılarının kurduğu encümenlerde Seyahatnâme'den başka siyasal ideolojilerinin belirtildiği herhangi bir teori kitabı bulunmamaktaydı." Kirmânî, bu kitabı ona Seyyit Muhammed Tabâtabâî'nin verdiğini, ülkenin kötü gidişatına dur demek için gizli toplantılar düzenleyen aydınların, düzenlenen bu toplantılarda Seyahatnâme' yi okuduklarını ve bu kitab1 okurken bazen hüzünlendiklerini hatta ağladıklarını da belirtmektedir (Kirmânî 1357: 245,248). Târîh-i Meşrûte-i Irân adlı çalı̧̧masında Ahmed Kesrevî ise Seyahatnâme'nin özgürlükçü çevreler ve aydınlar üzerindeki etki ve önemine ilaveten bu kitabın İran halkında oluşturduğu derin etkiden şöyle bahsetmiştir: "Bu kitabın kadrini o günlerde onu okuyanlar ve okuyucu üzerinde yarattığı sarsintıyı hatırlayanlar bilirler. O günlerde, çirkinliklere ve kötülüklere alışmış olan, kendi kötü yaşamlarından başka bir yaşam tasavvur edemeyen geniş bir Iranlı kitle, bu kitabı okuyarak sanki uykudan uyanmış, derinden sarsılmışlardl. Bu kitabı okuyarak ülke yararına çalışmak için hazır hale gelmiş ve diğer mücadeleci kişilere katılmış 
olan pek çok kişi bulmak mümkündür" (Kesrevî 1363: 45-46). Kesrevî ayrıca, ülkedeki istibdat zamanında böylesine bir kitabı yayınlayarak gösterdiği cesaretten ötürü Merâgaî için övgü dolu sözler de söylemiştir. Abdullah Mustevfî ise Zindegî̀-yi Men adlı kitabında, Merâgaî'den bahsederek hükümetin meşrutiyeti kabul etmesindeki en büyük faktörün Talîbof'un Kitab-i Ahmed'i, İkbâlu'dDevle'nin Risaleler'i ve Merâgâ̂'nin Seyahatnâme'sine ait olduğunu belirterek bu kitapları dönemin en önemli üç eseri olarak kabul etmiştir (Mustevfî 1388: 20). Benzer şekilde, Ferîdûn Âdemiyyet, İdeûlûjî-yi Nehzet-i Meşrûte-i Irân kitabında, bu eserden İranlıların düşünce tarihini değiştiren kitap olarak bahsetmiş ve şöyle devam etmiştir: "Seyahatnâme, Iran toplumsal hayatının ekonomi, inanç, eğitim, ahlak gibi her yönüne yapılan bir eleştiridir. Yazarın en önemli görüşü değişen dünya düşüncesidir. Eserde köhne alışkanlıklara ve hurafelere saldırmış, gelişmenin değerinden ve gereklilĭginden bahsetmiştir. Tüm eserde yapılan eleştirinin temel kaynağı bu olmuştur." (Âdemiyyet 1980: 88). Kerîm Kişâverz ise Hezâr Sâl-i Nesr-i Pârsî’nin üçüncü cildinde, eserin yayınlanmasıyla Almancaya çevrilmesinin eş zamanlı olduğunu ve bu kitabı okuyan yurtdışındaki genç İranlıların ülkelerini ziyaret etme hevesiyle dolduğunu söylemekte ve eserin Kâçâr döneminde ülkede yaşanan düzensizliklere ve baskıcı hükümetin yaptığı haksızlıklara muhalefet ve eleştiri olarak yazıldığııı belirtmektedir (Kişâverz 1371: 1270). Merâgaî'nin kendisi de Seyahatnâme'nin ikinci ve üçüncü ciltlerinde, birinci cildin yayınlanmasının ardından, yöneticilerin kitabı okuyanları cezalandırmak için çeşitli yollara başvurmalarına rağmen İran halkının kitaba gösterdiği ilgiden bahsetmiş, bu kitabın geniş kitleler, çeşitli toplumsal gruplar üzerinde hatta İran yönetim sınıfının içinde dahi etkisinin olduğunu belirtmiştir. Bu ifadelerden de hareketle, İran halkının yabancı karşı1tı olmasında ve ülkedeki anti sömürgeci hareketin büyümesinde, halkın bilinçlenerek vatanlarını koruma yolunda harekete geçmesinde Merâgaî'nin hayatî bir rol üstlendiği ileri sürülebilir.

\section{Yazarın Biçemi ve Eserin Edebî Önemi}

Merâgaî, Fars edebiyatında seyahatname türündeki ilk öykü yazarlarından biridir. Bu türe öncülük etmesinin yanı sıra yazar, düz yazının sadeleştirilmesinde etkin bir rol üstlenmiştir. Yazılarında sıklıkla bu konuya dikkat çektiği 
görülen yazar “Günümüzün gereği, sade yazımdır, kaleminde ve düşüncelerini ortaya dökmekte yeteneği olan Iranlı edebiyatçıların gerek düzyazıda gerekse şiirde vatan sevgisini anlaşılır kelimelerle halka sunmalarl, aynı zamanda sade yazımı teşvik etmeleri gerekmektedir" demektedir (Âryenpûr 1379: 307). Benzer olarak, Merâgaî edebiyatçıların ülke refahını göz önünde bulundurmaları gerektiğini, bunun vatanî bir görev ve sorumluluk olduğunu ifade ederek aynı zamanda eserlerinde hangi biçemi tercih ettiğini de açıç̧a göstermektedir: "Artık efsane ve anlamsı derecede romantik şeyler yazllmasl yerine kutsal vatanı iyileştirmek ve onu korumak adına eserler kaleme alınmalı" veya "Halkın saltanatın şahsına karşı ayaklanması maksada uygun olsa da, bendeniz, bunun hatanin ta kendisi olduğunu düşünüyorum. Bu düşüncede ve hayalde olan hiç kimseyi beğenmiyorum. Bugün Iran için hiçbir tehlike, millet ve devlet için bütün belalara ve afetlere davetiye çıkaran bu iç ayaklanmalar kadar zararlı değildir. Mevcut anarşinin ıslahı, padişahın yüksek düşüncelerine ve milletin kendi haklarını tanımasına bağlıdır. Bu yüzden, şaha, yağmacıların zulmüne razı olmaması ve hoş görmemesi gerektiği anlatılmalıdır. Bir gün memleket büyüklerinin bu kusurlarl ve bozukluklarl, yiğitçe bir hareketle düzeltecekleri umulur." (Âdemiyyet 1980: 99-100). Bu bağlamda, Merâgaî 1895 y1lında bas1lan, daha sonra ikinci ve üçüncü ciltleri yayımlanan ve aslında hayalî bir seyahatname olan İbrahim Beg'i, halkın ulusal kimliğini ortaya çıkarmak, ülkedeki kötü gidişatı gözler önüne sermek ve yöneticileri uyarmak için kaleme almıştır. Buna göre, kitaptaki karakterlerin maceraları ikinci dereceden öneme sahiptir, yazarın asıl gayesi ülke yaşantısının bir tasvirini yaparak gördüğü her eksiklik ve olumsuzluk için eleştiri ve itirazlarını dile getirmek, ülkede yaşanan sorunlara dair halka veya yönetimdeki ilgili kişilere çözüm önerisi sunmaktır.

Seyahatnâme çağdaş İran edebiyatının gelişimine de önemli katkılar sunmuştur. Her ne kadar eserin edebî değeri, siyasal ve toplumsal değerinin gölgesinde kalmış olsa da, Avrupaî tarzda yazılan ilk Farsça toplumsal roman olması bakımından tarihî bir öneme sahiptir. Bununla birlikte, eleştirmenlere göre eserde bazı sanatsal ve teknik kusurlar bulunmaktadır. Özellikle ikinci ve üçüncü ciltte işlenen olayların seyri birinci ciltte olduğu kadar sağlam bir yapıda değildir. Genel olarak sade ve akıcı bir dille yazılan eserde kimi zaman belirtilen 
olaylar ve olayların gerçek kronolojileri birbirine girmiştir. Bazı yer isimlerinin yanlış verilmesi ise Merâgaî’nin aslında o yerleri görmediğini göstermektedir, ancak kurgusal bir seyahatname olan eserde bu gibi küçük olumsuzlukların görülmesi bizce çok büyük bir eksiklik olarak değerlendirilmemelidir. Bunlara ek olarak eserde nesnel gözlemlere, öznel tasvirlere, doğrudan ve dolaylı anlatımlara yer verilmesi veya öğüt içeren atasözlerinin yoğun olarak kullanılması yazarın biçemindeki eksikliği değil meşrutiyet nesrinin bir özelliğidir'; ancak yazarın uzun seneler Osmanlı ve Rusya'da yaşaması, ilaveten yazarın Nikola $\mathrm{Gogol}^{2}$ gibi Rus edebiyatçılara olan hayranlığı, kompozisyonunda etkisini hissettirmekte, özellikle Türkçe yazım tarzı açık şekilde esere yansımaktadır. Bu paralelde eserde kimi zaman ('vekîl-i modâfe' yerine 'abukat', 'nümâyişgâh' yerine 'ifầ -i ekspozisyon', 'râh-i âhen' yerine 'şemendefer', 'kânûn' yerine 'yasa', 'âteşsuzî' yerine 'yangın', 'kârhâne' yerine 'fabric', 'acele kon' yerine 'haydi’ v.b.) Türkçe ve Rusça kelimeler, kimi zaman ise Fransızca veya Almanca kelimelerin kullanımı görülmektedir. Bazı eleştirmenler tarafından, bu durumun Türkçe, Rusça ve Latin kökenli kelimelere aşina olmayan okur için anlatımı zora soktuğu iddia edilmiştir (Sobhânî 1384: 588; Kanar 1999: 95). Kanımca, Merâgaî'nin İran dışında yaşaması neticesinde, yaşadığı yerlere ait bazı dilsel unsurları eserine dâhil etmesi İranlı okur için anlatımı mübalağalı şekilde güçleştirmediği gibi İranlı olmayan okur için eseri bir bakıma cazip hale getirmiştir. Eleştirmenler tarafından belirtilen bu eksiklik hususunda eserde tespit edilen bu gibi kullanımlar şu şekilde örneklendirilebilir

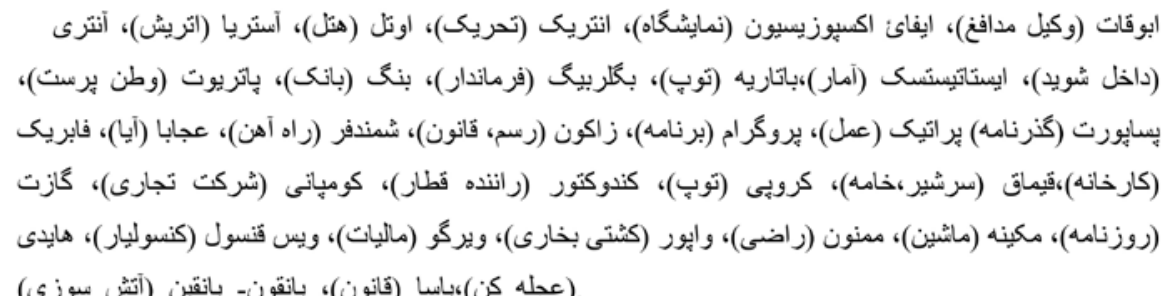

1 Meşrutiyet Dönemi nesir özellikleri için bkz. Zebîhullâh-i Safâ, İran Edebiyatına Genel Bir Bakış, s.104-106. 2 Yahya Âryenpûr, Seyahatnâme’nin Nikola Gogol'un Ölü Canlar eseriyle birçok yönden benzerlikleri olduğunu söylemektedir. Bkz. Ez Sabâ tâ Nîmâ, C.I., s.310.

3 Sözcüklerin Farsçası parantez içinde verilmiştir. 
Eserde aynı zamanda imla hataları da göze çarpmaktadır, bunun yazarın küçük yaşlardan itibaren yurtdışında yaşamasının bir sonucu olduğu düşünülebilir. $\mathrm{Bu}$ tip hatalar eserde şu şekilde tespit edilmiştir4:

$$
\begin{aligned}
& \text { ار اس (ارس)، خو اموشى (خاموشى)، يزيرفت (بذيرفت)، بعات (بساط)، رازى (راضى)، صرفه (سرفه)، طولونبه }
\end{aligned}
$$

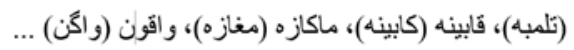

Eleştirmenlerin eserle ilgili önemli başka tespitlerde bulundukları da görülmektedir: Buna göre, Kerîm Kişâverz, Hezâr Sâl-i Nesr-i Pârsî̀ de, eserin sade bir anlatımı olmasına rağmen, Mısır'da ve İstanbul'da yaşayan İranlılara ait bazı özel ifadeler ve terimler içerdiğini söylemekte ancak bu durumun okuyucu açısından anlatımı zora sokmadığını ilave etmektedir (Kişâverz 1371: 1270). Bozorg Alevî de, eser ve yazarın biçemi hakkında benzer bir yorumlamada bulunmaktadır: "Şüphe götürmeksizin Merâgâ̂'yi yeni Fars edebiyatının öncülerinden kabul etmek gerekmektedir. Bununla birlikte, onun eserlerinde göz ardl edilemeyecek bazı eksiklikler de mevcuttur. Eserin yazıldığı dönemin şartlarından kaynaklı üslupla ilgili bazı kullanım yanlışları göz ardı edilecek olsa da yazar Türkçe istılahları Farsçaya olduğu gibi tercüme etmiştir. Bu durum bazı yanlışları doğurmuştur. Bu gibi yanlışların basımdan kaynaklanması ihtimali uzaktır. Ayn nokta şunu da göstermektedir ki yazar eserlerini sadece vatana duyduğu sevgi neticesinde yazmıştır. İran'ın içinde bulunduğu şartlar ile yabancı ülkelerdeki şartlar arasındaki farklılı̆̆l gözlemleyerek Iran'ın ilerlemeye ve halkı özgürce yaşamaya ihtiyacı olduğunu dile getirmek istemiştir. Merâgâ̂ olay yazarı değildir, Iranlıların uyanışı, bilinçlenmesi için sadece kendi arzu ve isteklerini beyan etmiş, bu bağlamda eserinde gerçeklerden yola çıkarak kendine ait bir dünya kurgusuna yer vermiştir. Sonuç olarak, Merâgaî'nin İran edebiyatının yenileşme hareketinde takdire şayan bir yardımı olmuştur." (Alevî 1386: 106). Hasan-i Mir Âbidînî de, Iran Öykü ve Romanının Yüz Yllı'nda Merâgaî ve eseri hakkında şöyle bir değerlendirmeye yer vermiştir: "Seyahatnâme-i İbrahim Beg, yeni bir bakış açısıyla ve sade bir nesirle yazılmış bir yolculuk öyküsüdür” (Âbidînî 2002: 7). "Hac Zeynülabidin-i Merâgaî (1839-1911) İstanbul'da yaşayan bir tacirdir. Seyahatnâme-i İbrahim Beg ya Belâ-yi Taassub-i U adlı 
eseri 1895, 1896 ve 1900 yılları arasında üç cilt olarak yayımlanmıştır. Birinci cilt hangi açıdan bakarsak bakalım en başarılı cilttir. Konuları birbirine bă̆lı ve düzenlidir. Ancak bu düzenli anlatım öteki iki ciltte çok fazla göze çarpmaz. Iran halkının hayatının gerçekçilikle canlandırılması, derin bir yurtseverlik, Iran toplumunun her açıdan eleştirilmesi, birinci cildi kargaşa dolu meşrutiyet dönemi gerçekçiliğinin canlı bir örneği haline sokmuştur." (Âbidînî 2002: 7,8). Kanımca yapılan bu tespitler yerindedir. Belirtilmesi gereken temel unsur, yazarın eserindeki önceliği eserinin konusu ve eserinde vermek istediği mesajıdır.

Bahsedilen eksikliklerin özellikle üçüncü ciltte yer alması ve ilk iki cildinde kimliğini gizleyen Merâgaî’nin, üçüncü ciltte eserin yazarı olduğunu açıklaması bazı eleştirmenlerce inandırıcı bulunmamış ve eserin başka bir yazar tarafından kaleme alındığı düşüncesine neden olmuştur. Bazı yazarlarsa eserin yazarının kendileri olduğunu iddia etmişlerdir. Hatta bu kişiler Mîrzâ Ali Asger Han Atabek'in emriyle, kitabın yazarı olma ithamıla tutuklanmış, takip edilip gözaltına alınmışlardır (Âryenpûr 1379: 307). Bu konuyla ilgili olarak Ali Ekber Dihhodâ ise Merâgaî'yle ilgili bir anısında şunları söylemektedir: “Iran'da meclisin topa tutulmasının ardından İstanbul'a gittim. Bir gün yaşlı bir adam ziyaretime geldi ve kendini Merâgaî olarak tanıttı." Dihhodâ'nın aktardığına göre, ziyaretin devamında Merâgaî, ona gençlik yıllarından söz etmiş; Merâga'yı terk edip Kafkasya'ya gittiğini ve yaşadığı olayları anlatmıştır. Sohbet esnasında ayrıca Seyahatnâme' nin yazarının kendisi olduğunu söylemiş, ancak Osmanlı' da onun söylediklerine inanılmadığından bahsetmiştir. Dihhodâ, yazısında Merâgaî'nin anlattıklarına ve kitabın yazarının o olduğuna inandığını da belirtmektedir (Merâgaî 1323: 9).

Eleştirilerin bir diğeri eserin konusunun özgünlüğüne yöneliktir. Âdemiyyet, Seyahatnâme'yi kaleme alırken Merâgaî'nin Ahter gazetesi yazarı Mîrzâ Âğâ Han Kirmânî'den yararlandığını, eserin bazı yerlerinde ondan esinlendiğini söylemektedir. Bunu, Mîrzâ Â̆gâa Han Kirmânî'nin yapıtlarında yer alan 'İrancılık' gibi bazı özel terim ve ıstılahların bu eserde kullanılmasıyla açıklamaktadır. Âdemiyyet bir diğer eleştirisini eserin giriş bölümü için yapmaktadır. Ona göre, bu bölümdeki fikirler dönemin vezirlerinden Eminu'd-Devle’ye aittir. Ancak Merâgaî'nin, bu devlet adamını hiç görmediği ifade edilmelidir. Fikirler arasındaki bu benzerlik Eminu'd-Devle'yi iyi tanıyan birinden ki bu büyük olası- 
lıkla Mîrzâ Âğâ Han Kirmânî’ dir, bu sözleri duyup kullanmış olmasıyla ilişkili olabilir (Âdemiyyet 1980: 86-87). Kanımca, böylesi benzerlikler eserin özgünlüğünden kuşku duyulmasına yol açmamalıdır. Çünkü 'metinlerarasılık' yani metinlerin anlamının diğer metinler tarafından şekillendirilmesi edebî bir kullanım biçimi olup metni zenginleştirmektedir. $\mathrm{Bu}$ da yazının değerini düşürecek bir unsur değildir. Aksine çoğu metinde olan bir özelliktir. Zira "Hiçbir metin üretici, üreteceği metnin konusu, biçimi ve metinde kullanacağı biçem ile ilgili bir bilgi birikimine sahip olmadan yeni bir metin üretemeyecektir. Bu birikimini de daha önce okuduğu metinlerden edinecektir. Dolaylslyla ürettiği metinde önceki metinlerin izleri kaçınılmaz olacaktır" (Torusdağ\&İşimtekin 2016: 177). $\mathrm{Bu}$ eserde de bu durumun söz konusu olduğu düşünülmektedir. Yazarın, bazı aydınların düşüncelerinden yararlanarak, Talîbof'un eseri Kitab-i Ahmed'ten ilham alarak ve Avrupaî eleştirel romanlarından da esinlenerek yazdığı bu eserle vatandaşlarının zihninde ve vicdanında derin bir etki yaratmasının önemli sebeplerinden birisi bizce budur.

Eser'in edebî yönü hakkında bahsedilen olumsuzluklara rağmen eser, konusu ve konusunun işlenme biçimi bakımından, yukarıda da bahsedildiği üzere Fars edebiyatında bir ilk olma özelliği taşımaktadır. Eser özellikle hicviye biçiminde klasik üslûpta ama sade bir dille ve büyük bir ustalıkla yazılmıştır. Okur kitabı okurken hikâyenin içine kolaylıkla girmekte, hikâyeyi adeta yaşamaktadır. Birçok eleştirmene göre Seyahatnâme'nin yayımlanmasından önce de bu tarzda kitaplar basılmış ama hiçbiri bu kadar revaç kazanmamış ve halkı etkilememiştir. Çünkü diğer kitaplar sanatlı bir dille yazılmışlardır. Bu kitapta ise yazar düşüncelerini dile getirmek için konuşma dilini tercih etmiştir ki kanımca, yazarın eserinde önem verdiği ikinci temel unsurdur da bu olmuştur. Yazar, kitabında verdiği canlı sahneler, yaşanan diyaloglar ve biçemi kendinden sonraki yazarlar için bilgilendirici bir kılavuz görevi üstlenmiş ve Fars nesrinin gelişimine büyük bir katkı sağlamıştır.

\section{Sonuç}

Seyahatnâme-i İbrahim Bey'in temel izleği, vatanseverlik ekseninde İran'ın geri kalmışlı̆ğna yapılan bir eleştiri ve bu geri kalmışlığa sunulan bir çözüm önerisidir. Üç ciltlik bu eserin Merâgaî'nin eleştiri, mizah ve öfkesinin bir kar1- 
şımı olduğu söylenebilir. Kitabın etkili olmasının nedeni, sade bir dille yazılmış olmasıdır. Kitapta abartılı ve yapmacık bir kurgu bulunmamakta ve okuyucu, o günlerde kendisinin de yaşadığı, gözlemlediği olayları ve maruz kaldığı kötü durumları bu eserde görebilmektedir. Tabiî ki eserde bir takım teknik kusurlar bulunmaktadır ancak bazı eleştirmenlerce izleğin özgünlügü ve yazarın biçemi hakkında belirtilen eksiklikler, bize göre eserde bulunması gereken unsurlar olarak tespit edilmiştir.

Eserin başkarakteri İbrahim Bey, aslında birçok açıdan kitabın yazarı Merâgaî’ye benzemektedir. Yazar bir bakıma hayatını kitaba uyarlamıştır ve yaşadıklarını İbrahim Bey aracılığıyla okuruna aktarmıştır. Çünkü Merâgaî gibi kendisi de yurtdışında yaşayan İbrahim Bey, zengin bir tüccarın oğludur ve İran'ın mevcut düzenini, yönetim şeklini beğenmemektedir. Dahas1, Merâgaî’nin kendini roman kişisi olarak, üst kurmaca biçiminde, metne dâhil etmesi ve romanın başkişisi İbrahim Bey ile bu bağlamda birebir diyaloga girmesi kanımca bu görüşü destekler niteliktedir.

Eserde, İranlı bir gencin anı defteri ile Mısır'dan ayrılıp dünyayı görmesi ve çeşitli yerlere seyahat etmesini vasiyet eden babasının son arzusu üzerine anavatanını görmek amacıyla çıtı̆̆ı seyahatte yaşadıkları anlatılmaktadır. $\mathrm{Bu}$ hayalî yolculuk esnasında İranlıların beğenilmeyen davranışlarına, ülkede yaşanan ahlakî yozlaşmaya ve batıl inançlara yerinde ve yoğun bir eleştiri yapılmaktadır. Ek olarak, o dönemde İran'ın dış devletlerle olan ilişkisi de gözler önüne serilmekte ama diğer ülkelerin İran ve İranlılara olan kötü tutumları da açık bir dille eleştirilmektedir. Bir başka anlatımla, İran'da kötü muamele gören ve yaşama zorluğu çeken insanların kötü şartlar altında dış ülkelerde yaşamalarına ve İran devletinin, yabancı ülkelerin yaptığı bu kötü davranışa sessiz kalmasına doğrudan bir yergi vardır. Hikâyenin izleğindeki vatanseverlik ve millî duyguların kimlik kazanması için gösterilen çaba, aslında Merâgaî’nin İbrahim Bey aracılığıyla sonraki nesillere öğüt niteliğindeki mesajıdır. 


\section{Kaynakça}

Âdemiyyet, Ferîdûn (1980), İdeûlûjî̀-yi Nehzet-i Meşrûtiyet-i Irân, Tahran: Kânûn-i Ketâb-i İrân.

Alevî, Bozorg (1386), Târîh-i Edebiyât-i Mu âsır-i İrân, Tahran: Câmî.

Âryenpûr, Yahya (1379), Ez Sabâ Tâ Nîmâ, Cilt I, Tahran: İntişârât-i Zevâr.

Ekber, Muhammed Ali (1384), "Seyahatnâme-i İbrahim Beg; Beyâniyye-yi Aleyh-i Vez -i Movcûd”, Homayeş-i Yeksedomîn Sâlgerd-i Meşrûtiyet, Tahran: Dânişgâh-i Tahran, 72-96.

Kanar, Mehmet (1999), Çağdaş İran Edebiyatının Doğuşu ve Gelişmesi, İstanbul: İletişim.

Kesrevî, Ahmed (1363), Târîh-i Meşrute, Cilt I, Tahran: Sepehr.

Kirmânî, Nâzımu'l-İslâm (1357), Târîh-i Bîdârî-yi İrânîyân, İsfahan: Âgâh.

Kişâverz, Kerîm (1371), Hezar Sal-i Nesr-i Parsi, C.III, Tahran: Sehâmî.

Merâgaî, Hâc Zeynülâbidin-i (1323), Seyahatnâme-i İbrahim Beg ya Belâ-yi Taassub-i U, Cilt I-III, İsfahan: Âgâh.

Mîr Âbidînî, Hasan (2002), İran Öykü ve Romanının Yüz Yılı I, Çev: Derya Örs, Ankara: Nüsha.

Mustevfî, Abdullah (1388), Zindegî-yi Men, Cilt II, Tahran: İntişârât-i Zevâr.

Safâ, Zebîhullâh-i (2003), İran Edebiyatına Genel Bir Bakış, Çev: Hasan Almaz, Ankara: Nüsha.

Sobhânî, Tevfik (1386), Târîh-i Edebiyât-i İrân, Tahran: İntişârât-i Zevâr.

Torusdağ, Gülşen ve İşimtekin, Soner (Aralık 2016), "Furug Ferruhzâd'ın "Kâbus” Öyküsü Üzerine Metindilbilimsel Bir Çözümleme”, A.Ü. DTCF Dergisi 56.2: 160-199. 